\title{
PENEGAKAN KEAMANAN MARITIM DALAM NKRI DAN PROBLEMATIKANYA
}

\section{(Enforcement of Maritime Security in the Unitary States of the Republic of Indonesia and Problems Thereof)}

\author{
Suharyo \\ Badan Penelitian dan Pengembangan Hukum dan HAM \\ Jalan H.R. Rasuna Said Kav 4-5, Jakarta Selatan 12920 \\ HP. 08158860437 \\ suharyodenkes@gmail.com
}

Tulisan Diterima: 19 Agustus 2019; Direvisi: 12 September 2019; Disetujui Diterbitkan 13 September 2019 DOI: http://dx.doi.org/10.30641/dejure.2019.V19.285-302

\begin{abstract}
Enforcement of the maritime security in the territory of the Unitary States of the Republic of Indonesia (NKRI), is a manifestation of the rule of law and the sovereignty of the territorial waters of NKRI. The Republic of Indonesia has 17,499 islands, with a sea area of 5.8 million $\mathrm{km} 2$ has still been facing some problems in materializing its maritime security and law enforcement at sea. First, why the law enforcement of maritime security in the NKRI has not been optimized, and second, what efforts should we make to optimize this law enforcement of maritime security. The method employed is normative juridical research. Maritime crimes are highly diversed, the crimes that always happen here are fish theft and various other crimes. The unsettled delineation of Indonesian boundaries with the other neighboring countries at some points has made the law enforcement against the fish theft and others crimes more difficult. In the globalization era, like now and in the future, Indonesia is facing not only the crimes at sea that are still rampant, but also disputes over sea borders with neighboring countries, as well as sea reclamation from Singapore that has the potential to change its boundaries with Indonesia and Malaysia. NKRI as the largest unitary states in the world, must be able to maintain and enforce its maritime security. Covenants on sea boundaries with neighboring countries must not be allowed to drag on. Relevant agencies, from the Ministry of Foreign Affairs and other agencies, must quickly respond to these covenants with the neighboring countries by strengthening the facilities and infrastructure, human resources, budgets and consistent state policy.
\end{abstract}

Keywords: maritime security of the republic of Indonesia.

\begin{abstract}
ABSTRAK
Penegakan keamanan maritim dalam wilayah NKRI, merupakan perwujudan penegakan hukum dan kedaulatan wilayah laut teritorial NKRI. Eksistensi NKRI yang mempunyai 17.499 pulau, dengan wilayah laut 5,8 juta $\mathrm{km}^{2}$ masih terkendala dalam merealisasikan keamanan maritim dan penegakan hukum di laut. Sebagai permasalahan, pertama, mengapa penegakan hukum keamanan maritim dalam wilayah NKRI belum optimal, kedua, upaya-upaya apa yang seharusnya dilakukan agar penegakan hukum terhadap keamanan maritim dapat optimal. Metode yang dipakai adalah penelitian yuridis normatif. Kejahatan di laut sangat beragam, yang selalu terjadi adalah pencurian ikan dan berbagai kejahatan lainnya. Belum tuntasnya batas wilayah laut Indonesia dengan negara tetangga di beberapa titik, menyebabkan kejahatan pencurian ikan dan yang lainnya menjadi sulit untuk penegakan hukumnya. Dalam era globalisasi seperti sekarang dan dimasa mendatang, masih diwarnai berbagai kejahatan di laut, belum termasuk sengketa batas wilayah laut dengan negara tetangga, serta reklamasi laut dari Singapura yang berpotensi merubah batas wilayah laut dengan Indonesia dan Malaysia. NKRI sebagai negara kesatuan terbesar di dunia, harus mampu menjaga dan menegakkan keamanan maritim
\end{abstract}


dalam NKRI. Perjanjian garis batas laut dengan negara tetangga tidak boleh dibiarkan berlarut-larut. Instansi terkait mulai dari Kementerian Luar Negeri dan instansi lainnya harus cepat merespon perjanjian perbatasan laut dengan negara tetangga. Penguatan sarana dan prasarana, SDM, penganggaran, dan konsistensi serta kebijakan negara.

\section{Kata kunci: keamanan maritim NKRI}

\section{PENDAHULUAN}

Dalam Buku Putih Diplomasi Martitim Indonesia 2019, disebutkan terdapat 4 (empat) sasaran diplomatik maritim Indonesia, yakni : perlindungan kedaulatan wilayah laut Indonesia, tercapainya kesejahteraan masyarakat dan keterhubungan antar wilayah, kestabilan kawasan, dan penguatan kapasitas nasional. ${ }^{1}$

Empat sasaran diplomatik maritim Indonesia, dari waktu ke waktu semakin melengkapi AGHT, baik yang berasal dari dalam negeri Negara Kesatuan Republik Indonesia (NKRI), dengan jumlah pulau sekitar 17.000 pulau besar dan kecil, baik yang berpenghuni maupun kosong. Yang mempunyai wilayah lautan lebih luas jika dibandingkan dengan luas daratan, sampai sekarang masih banyak terkendala dalam mewujudkan keamanan maritim dan NKRI.

Secara spesifik, Indonesia merupakan negara kepulauan yang memiliki 17.499 pulau dengan wilayah lautnya 5,8 juta $\mathrm{km}^{2}$ atau $2 / 3$ wilayah Indonesia merupakan lautan. Dengan kondisi demikian, maka kepentingan nasional Indonesia sejatinya bertumpu pada bidang maritim. $^{2}$

Konsepsi keamanan maritim merujuk pada PBB, diantaranya menyangkut :

1. Pembajakan dan perompakan;

2. Terorisme maritim (maritime terrorism);

3. Peredaran senjata ilegal;

4. Perdagangan manusia;

5. Imigran gelap;

6. Pencurian ikan;

1 Kompas, Diplomasi Maritim Kebijakan Kelautan Berorientasi Keluar, Sabtu 23 Februari 2019.

${ }^{2}$ Marsetio, Sea Power Indonesia, Cetakan Pertama April 2014, Penerbit Universitas Pertahanan, Jakarta 2014 hlm. 91.
7. Pencemaran lingkungan laut. ${ }^{3}$

Khusus keamanan maritim yang menjadi ancaman tambahan dan belum sepenuhnya dapat dituntaskan adalah illegal loging, penyelundupan bahan bakar minyak, dan penyelundupan sembilan bahan pokok lainnya. Berbicara tentang keamanan maritim di NKRI, sudah barang tentu terkait dengan pertahanan negara di laut Indonesia.

Adapun pada Kawasan Perairan Natuna dan Laut Tiongkok Selatan merupakan kawasan rawan pencurian ikan. Pencurian ikan didominasi nelayan asal Vietnam, Thailand dan Tiongkok. Kerugian negara akibat pencurian ikan diperkirakan mencapai 80 triliun rupiah, sekitar 50 triliun adalah kerugian pajak, sisanya merupakan kerugian yang timbul dari potensi ikan yang hilang. Demi menanggulangi illegal fishing di wilayah Indonesia, mulai 2011 ditetapkan prioritas untuk operasi di laut, yaitu Perairan Natuna, khususnya di Laut China Selatan, Sulawesi Bagian Utara, Laut Sulawesi dan Utara Halmahera, dan Laut Arafura, yang terkenal banyak ikannya dan menjadi incaran pelaku illegal fishing. ${ }^{4}$

Konflik politik dan bersenjata yang berkepanjangan di Afghanistan, Irak, dan Sri Lanka menyebabkan terjadinya aliran pengungsi ke luar negeri, di mana Australia yang berada di bagian selatan kawasan Asia Tenggara merupakan salah satu negara tujuan. Indonesia merupakan negara transit yang harus dilalui para imigran ilegal untuk menuju Australia, sehingga Pemerintah Australia berharap Indonesia dapat berperan sebagai buffer zone pencegah masuknya imigran ilegal ke negaranya.

Melonjaknya jumlah imigran ilegal di Indonesia bukan saja karena secara geografis

3 Angga Nurdin Rachmat, Keamanan Global Transformasi Isu Keamanan Pasca Perang Dingin. Penerbit Alfabeta Bandung 2015 hlm. 177-195.

${ }^{4}$ Bernhard Lembong. Poros Maritim. Penerbit Margaret Pustaka. Jakarta. 2015. hal. 359. 
Indonesia merupakan negara terdekat dengan Australia. Tetapi juga disebabkan karena Pemerintah Indonesia lemah dalam pengawasan kawasan perbatasannya. Sebagai negara kepulauan, Indonesia memiliki pintu masuk yang cukup banyak. Tanpa adanya pengawasan yang ketat di perbatasan, Negara Kepulauan Indonesia bagaikan halaman tanpa pagar yang mudah dimasuki siapa saja. ${ }^{5}$

Penampungan imigran ilegal di Indonesia, sampai September 2019, terus menerus menjadi pekerjaan rumah yang sangat besar bagi Pemerintah Indonesia, dan Pemerintah DKI Jakarta. Imigran ilegal yang berjumlah 1200 orang, seperti dalam pemberitaan berbagai media masa, sangat mengganggu keamanan, dan ketertiban masyarakat. Setelah berkeliaran di Kawasan Kebon Sirih, dan Jalan Sabang mereka ditampung di bekas Kantor Kodim Jakarta Barat. Sekarang, para imigran ilegal ada yang bertahan di bekas Kantor Kodim Jakarta Barat, dan sebagian lainnya diberi uang saku oleh United Nation High Commissioner for Refugees (UNHCR) untuk mencari kontrakan.

Sejarah keseringan kehadiran negara dalam mempertahankan keamanan maritim di laut Indonesia, sekaligus mempertahankan kedaulatan di laut Indonesia, dapat dikatakan timbul tenggelam masa keemasan sebagai perwujudan negara maritim, tidak lain pada saat awal kemerdekaan. Pada masa itu Presiden Soekarno yang bertekad bulat menyatukan dan menegakkan NKRI, sekaligus mengusir penjajah Belanda dari Irian Barat.

Politik hukum dan politik luar negeri yang dibangun, sekaligus keseriusan dan keberanian mengusir penjajah Belanda dari Irian Barat, dengan memperkuat pesenjataan TNI secara besarbesaran. Periode 1960-1965 TNI dan persenjataannya, termasuk TNI-AL sebagai negara terkuat di Asia. Pada saat yang bersamaan, negara lain di kawasan Asia, tetap bergelayut dengan keterbatasan dan kemiskinan. Sehingga di laut Indonesia sangat berjaya.

Keterpurukan kehadiran negara di laut Indonesia, melalui waktu yang sangat panjang dari periode 1965 sampai dengan tahun 1998. Walaupun ada kebijakan tambal sulam dari pemerintah pada masa itu, melalui pembelian 40 (empat puluh) kapal perang bekas dari Jerman
Timur, untuk mengganti puluhan kapal perang TNI-AL yang baik disengaja atau tidak, dibesituakan.

Krisis ekonomi dan krisis politik yang lama diselesaikan oleh beberapa pergantian pemerintahan, menyebabkan perhatian dan kehadiran negara di laut wilayah Indonesia, menjadi berkurang. Sementara itu pada saat yang bersamaan kebangkitan ekonomi dan semangat negara-negara Asia lainnya, melihat tidak berdayanya Indonesia dan lemahnya kemampuan menegakkan kedaulatan wilayah laut Indonesia. Padahal wilayah laut Indonesia mempunyai potensi perikanan yang sangat luar biasa. Dan pulau-pulau di Indonesia lainnya, mempunyai potensi hutan beserta hasil-hasilnya, termasuk sumber daya alamnya di pesisirnya.

Perhatian pemerintah terhadap laut Indonesia, dalam mewujudkan keamanan maritim, semakin ditingkatkan. Posisi Indonesia sebagai negara kepulauan, merupakan perbatasan lautan samudera Hindia dan Samudera Atlantik, suatu jalan perdagangan yang sangat sibuk di dunia. Potensi ekonomi dan pertumbuhan ekonomi menjanjikan, di tengah suasana damai kawasan negara-negara, laut Indonesia semakin menjadi rute tersibuk jalan lautnya. Sebagai implementasinya, keterbatasan dalam mewujudkan penegakan hukum di laut, Indonesia, menjadi peluang berbagai pihak untuk melanggar ketentuan perundang-undangan di laut. Penguatan instituti pengelolaan dan sekaligus penegakan hukum di laut melalui berbagai peraturan perundangundangan, masih banyak terkendala.

Sebagai permasalahan yang dapat diidentifikasi adalah :

1. Mengapa penegakan hukum keamanan maritim dalam wilayah NKRI belum optimal?

2. Upaya-upaya apa yang seharusnya dilakukan agar penegakan hukum terhadap keamanan maritim dapat optimal?

\footnotetext{
${ }^{5}$ Ibid, hal. 361-362.
} 


\section{METODE PENELITIAN}

Metode yang dipakai dalam penelitian ini adalah, penelitian hukum yuridis normatif yang mencakup penelitian terhadap asas-asas dan teori-teori hukum, sistematika hukum, taraf sinkronisasi vartikal dan horizontal, perbandingan hukum dan sejarah hukum. ${ }^{6}$ Data yang berasal dari bahan pustaka terpilih, peraturan perundang-undangan, dokumen, surat kabar yang terkait dengan penegakan keamanan maritim kemudian dianalisis secara mendalam. Penelitian ini bersifat diskriptik analitik yang ditujukan untuk mengungkapkan suatu masalah atau keadaan atau peritiwa sebagaimana adanya sehingga dapat mengungkapkan fakta yang sebenarnya. ${ }^{7}$ Tujuan dari penulisan ini untuk menemukan berbagai problema dalam penegakan keamanan maritim di negara hukum NKRI, dan mencoba mencari solusi yang terbaik bagi banyak negara.

\section{PEMBAHASAN}

\section{A. Faktor-Faktor Penyebab Belum Optimalnya Penegakan Hukum Keamanan Maritim dalam Wilayah NKRI}

Untuk lebih menyelaraskan penulisan dengan judul Penegakan Keamanan Maritim Dalam NKRI dan Problematikanya, teori yang digunakan adalah "Teori Penegakan Hukum". Penegakan Hukum merupakan hal yang sangat mendasar dalam negara hukum. Menurut Satjipto Rahardjo dijelaskan sebagai berikut, "Penegakan hukum adalah suatu proses untuk mewujudkan keinginan-keinginan hukum menjadi kenyataan." Yang disebut sebagai keinginan-keinginan adalah pikiran badan pembuat undang-undang yang dirumuskan dalam peraturan-peraturan hukum itu. ${ }^{8}$ Penerapan teori penegakan hukum, beranjak dari suatu pendalaman substansi bahwa penegakan keamanan maritim, merupakan bagian dari penegakan hukum.

Negara Kesatuan Republik Indonesia (NKRI) adalah sebagai negara kepulauan;

\footnotetext{
${ }^{6}$ Soerjono Soekanto \& Srimamudji. Penelitian Hukum Normative Suatu Tinjauan Singkat. Penerbit Rajawali Pers Jakarta 1990 hlm. 15.

${ }^{7}$ Hadari Nawawi. Metode Penelitian Sosial. Penerbit Gajahmada Press Yogyakarta 1993 hlm. 31.

8 Suharyo. Dinamika Peranan TNI dalam Penegakan Hukum dan Kedaulatan NKRI, Penerapan Keadaan
}

sedangkan wilayah perairan atau disebut juga sebagai perairan terorial (teritorial water) adalah bagian perairan yang wilayah suatu negara yang tunduk pada kedaulatan negara tersebut. Disamping itu pula, ada pula bagian perairan yang berada di luar wilayah yang tidak tunduk pada kedaulatan negara, misalnya adalah laut lepas (high seas). ${ }^{9}$

NKRI yang terletak diantara benua Asis dan benua Australia, diantara Samudera Hindia dan Samudera Pasifik, juga berbatasan darat, dan laut dengan bagian negara tetangga. Menurut (Marnixon R.C. Willa, 2006 : 157-161), batasbatas laut Indonesia adalah :

\section{a. Batas Laut Territorial Indonesia}

Batas laut teritorial Indonesia (BLTI) belum ditetapkan dengan Undang-undang, kecuali untuk batas di sebagian Selat Sungapura, yaitu dengan Undang-undang Nomor 7 Tahun 1973, dan bagian Selatan dari Selat Malaka dengan Undang-undang Nomor 2 Tahun 1971. Berdasarkan UNCLOS-82 dari Peraturan Pemerintah Nomor 38 Tahun 2002, secara umum BLTI dapat ditarik selebar 12 Mil Laut dari Garis Pangkal Kepulauan Indonesia. Daftar koordinat titik-titik Garis Pangkal Kepulauan tersebut telah diundangkan dengan Peraturan Pemerintah Nomor 38 Tahun 2002. Khsus Batas Laut Teritorial (BLT) di sebelah Barat dan Timur bagian Selat Singapura yang selebar kurang dari 24 Mil Laut diperlukan perundingan bersama (tripartid) antara Indonesia, Singapura, dan Malaysia.

Kemudian mengenai Batas Laut Teritorial (BLT) antara Indonesia dan Timor Leste di Selat Leti, Selat Wetar dan Selat Ombay, karena lebar selatnya kurang dari 24 Mil Laut, maka BLT antara kedua negara sedang diperundingkan. Delimitasi batas-batas maritim di Selat Ombay, Selat Leti dan di Utara Pulau Atauro harus ditetapkan dan dibagi sama rata bagi kedua negara. Disamping itu juga untuk kepentingan melancarkan pemakaian Alur Laut Kepulauan Indonesia (ALKI) di wilayah laut

Bahaya \& OMSP di Negara Demokrasi. Penerbit Pohon Cahaya. Yogyakarta 2016. Hlm. 19.

9 Laporan Penelitian Hukum Tentang Penegakan Hukum di Perairan Indonesia, BPHN Kemenkumham 2005. hlm.21 


\section{De Jure}

itu, karena tidak lagi dapat diperlukan sebagai perairan Kepulauan Indonesia. Dalam tataran normatif, Peraturan Pemerintah Nomor 37 Tahun 2002 Tentang Alur Laut Kepulauan Indonesia telah mengubar Rezim Perairan Kepulauan (Achipelagic Waters) di wilayah itu. Namun, tetap mempertahankan alur laut navigasi sebagaimana yang telah disetujui oleh IMO (International Maritime Organization).

\section{b. Batas Zona Ekonomi Eksklusif Indonesia}

Zona Ekonomi Eksklusif Indonesia (ZEE) secara umum ditetapkan dengan Undang-undang Nomor 5 Tahun 1985 Tentang Zona Ekonomi Ekslusif Indonesia (ZEEI), sedangkan menyangkut batas wilayahnya dalam Undang-undang Nomor 17 Tahun 1985 Tentang Pengesahan UNCLOS, yaitu selebar 200 Mil Laut diukur dari garis pangkal kepulauan, dimana daftar koordinat ada dalam Lampiran Peraturan Pemerintah Nomor 38 Tahun 2002, kecuali disegmen-segmen perairan yang berhadapan dengan negara lain yang lebarnya kurang dari 400 mil laut, seperti :

1. Laut Andaman yang berhadapan dengan India, lebar laut kurang dari 400 Mil Laut. ZEE akan berhimpit dengan batas laut kontinen (BLK)

2. Selat Malaka yang berhadapan dengan Thailand di bagian utara dan Malaysia di bagian Selatan, tetapi lebarnya kurang dari 400 Mil Laut. Di bagian Selatan antara Indonesia Malaysia masih ada beda pendapat, apakah ZEE berhimpit dengan batas laut kontinen atau tidak.

3. Selat Singapura yang berhadapan dengan Singapura dan juga Malaysia tidak ada ZEE, karena lebarnya hanya sekitar 15 Mil Laut.

4. Laut Natuna sebelah Barat dan sebelah Timur yang berhadapan dengan Malaysia, tetapi lebarnya kurang dari 400 Mil Laut. ZEE akan berhimpit dengan BLK.

5. Laut China Selatan yang berhadapan dengan Vietnam, tetapi lebarnya kurang dari 400 Mil Laut, masih dalam proses negosiasi.

6. Laut Sulawesi, dimana batas laut Indonesia berhadapan dengan Filipina dan jaraknya kurang dari 400 Mil Laut, belum ada perjanjian mengenai batas laut kedua negara.
7. Samudera Pasifik sebagian batas ZEE berhadapan dengan Negara Kepulauan Palau, dan jaraknya kurang dari 400 Mil Laut, belum ada perjanjian mengenai batas.

8. Laut Arafura dan Laut Timor yang berhadapan dengan Australia, dan jaraknya kurang dari 400 Mil Laut, telah disepakati bersama koordinat titik-titik batas laut.

9. Lautan Hindia disekitar Pulau Chrismas (Australia), dan jarak kurang dari 400 Mil Laut, telah disepakati bersama koordinat titik-titik batasnya di laut (tiga titik).

10.Laut Sawu kemungkinan akan terdapat batas ZEE/BLK antara Indonesia dengan Timor Leste, belum dirundingkan.

\section{c. Batas Landas Kontinen Indonesia}

Batas Landas Kontinen Indonesia (BLKI) secara umum ditetapkan dengan Undang-dengan Nomor 1 Tahun 1973 Tentang Landas Kontinen Indonesia, sedangkan menyangkut batasannya diatur dalam UndangUndang Nomor 17 Tahun 1985 tentang Pengesahan UNCLOS, yaitu akan ditarik sama lebar dengan batas ZEE (200 Mil Laut) atau sampai dengan maksimum 350 Mil Laut dari batas garis pangkal kepulauan Indonesia, kecuali di segmen-segmen garis :

1. Di Laut Andaman telah disepakati bersama sebanyak 10 titik BLK berikut daftar koordinatnya dengan India pada tahun 1974 dan tahun 1977.

2. Di Laut Andaman, telah disepakti bersama titik-titik BLK berikut daftar koordinatnya antara Indonesia dengan Thailand pada tahun 1977.

3. Di Laut Andaman telah disepakati bersama titik pertemuan juga garis batas (threejunction point) berikut daftar koordinatnya antara Indonesia, India, dan Thailand pada tahun 1978.

4. Selat Singapura bagian Utara telah disepakati garis BLK bersama antara Indonesia dan Thailand, dan juga telah disepakati secara trilateral antara IndonesiaThailand-Malaysia garis-garis BLK tiga negara di bagian Utara Selat Malaka.

5. Selat Malaka bagian Selatan telah disepakati bersama antara Indonesia dan Malaysia 
sebanyak 10 titik BLK, berikut daftar kkordinatnya.

6. Di Selat Singapura berhadapan dengan Singapura dan juga Malaysia tidak ada BLK karena lebarnya hanya sekitar 15 Mil Laut.

7. Di Laut Natuna di sebelah Barat dan sebelah Timur telah disepakati bersama antara Indonesia dan Malaysia sebanyak 15 Mil Laut BLK berikuat daftar koordinatnya.

8. Di Laut China Selatan, pada buan Juni 2003 antara Indonesia dan Vietnam telah ada kesepakatan mengenai BLK, dimana kedua negara telah berhasil memperkecil perbedaan mengenai wilayah yang disengketakan.

9. BLK di Laut Sulawesi masuk dalam agenda perundingan biletaral antara Indonesia dan Filipina sejak tahun 1994, tetapi masih belum ada kesepakatan tentang deliminasi batas wilayah laut baik BLK maupun ZEE.

10.Di Samudera Pasifik, wilayah laut Indonesia berbatasan dengan Negara Kepulauan Palau, masih belum ada perundingan.

11.Di Laut Arafura dan Laut Timor yang berbatasan dengan Australia dan jaraknya kurang dari 40 Mil Laut, telah disepakati bersama titik BLK kedua negara.

Adapun untuk mewujudkan dan menjaga NKRI sebagaai negara maritim, Presiden Joko Widodo pada awal pemerintahannya tahun 2014 mengetengahkan misi sebagai berikut, diantaranya yang terkait dengan keamanan maritim adalah: ${ }^{10}$

1. Mewujudkan keamanan nasional yang mampu menjaga kedaulatan wilayah, menopang kemandirian ekonomi dengan mengamankan sumber daya maritim, dan mencerminkan kepribadian Indonesia sebagai negara kepulauan.

2. Mewujudkan politik luar negeri bebas-aktif dan memperkuat jati diri sebagai Negara maritim.

10 Jokowi \& Jusuf Kalla, Jalan Perubahan untuk Indonesia yang Berdaulat, Mandiri dan Berkepribadian: Visi, Misi, dan Program Aksi, Jakarta, Mei 2014, diunduh dari https://www.bantuanhukum.or.id/web/wp-
3. Mewujudkan Indonesia menjadi Negara maritime yang mandiri, maju, kuat, dan berbasiskan kepentingan nasional.

Sedangkan untuk tindak pidana di laut, yang idetentik dengan kejahatan maritim; dalam beberapa referensi disebutkan adanya klasifikasi jenis-jenis tindak pidana di laut yang didasari atas berbagai Undang-undang pidana khusus. Misalnya dalam Buku Pegawai Perwira Koarmabar dikemukakan adanya beberapa jenis tindak pidana di laut, yaitu : ${ }^{11}$

\section{Tindak pidana dalam TZMKO Stbl. 1939} No. 442 da

1) Melakukan pengintaian atau survei Hidrografi di perairan Indonesia (pasal 12 ayat (1) huruf g jo pasal 9 ayat (1) huruf a);

2) Menggambar atau memotret dalam lingkungan maritim sehingga lingkungan maritim atau sebagian dari itu tampak gambar atau potret (Pasal 12 ayat (1) huruf g jo Pasal 9 ayat (1) huruf b);

3) Mengumpulkan bahan keterangan atau petunjuk yang berkenaan dengan lingkungan maritim dan untuk pertahanan (Pasal 12 ayat (1) huruf g jo Pasal 9 ayat (1) huruf c);

4) Dengan tanpa hak membuang jangkar atau sauh, berlabuh tinggal mengambang dengan kapal atau tongkang dalam lingkungan maritim atau perairan Indonesia (Pasal 12 ayat (1) huruf h jo Pasal 10 ayat (1)).

\section{Tindak Pidana Perompakan/Pembajakan di} Laut (KUHP)

1) Pembajakan (piracy) di laut lepas (pasal 438 KUHP jo Pasal 110 jo Pasal 105 jo Pasal 107 UNCLOS 1985);

2) Pembajakan di pantai atau perompakan (pasal 439 KUHP;

3) Pembajakan di pesisir (Pasal 440 KUHP);

4) Pembajakan di Sungai (Pasal 441 KUHP);

content/uploads/2014/06/VISI_MISI_Jokowi-JK.pdf, hlm. 6 .

${ }^{11}$ Laporan Penelitian Penegakan Hukum di Perairan Indonesia, BPHN Kemenkumham, Jakarta, 2015, hal 36-56. 
5) Nahkoda pekerja sebagai/menganjurkan melakukan pembajakan (Pasal 442 KUHP);

6) Bekerja sebagai Anak Buah Kapal di kapal yang digunakan untuk membajak (Pasal 443 KUHP);

7) Menyerahkan kapal untuk dibajak (Pasal 447 KUHP);

8) Penumpang merampas kapal (Pasal 448 KUHP);

9) Nahkoda melarikan kapal dari pemiliknya (Pasal 449 KUHP);

10) Bekerja sebagai Nahkoda atau Anak Buah Kapal di kapal yang digunakan untuk membajak (Pasal 450 atau 451 KUHP).

3. Tindak Pidana Senjata Api dan Bahan Peledak (Undang-undang Darurat Nomor 12 Tahun 1951)

Berdasarkan Undang-undang ini, hanya ada satu jenis tindak pidana, yaitu pengangkutan senjata api dan bahan peledak lewat laut, sebagaimana diatur dalam Pasal 1 Undangundang Darurat Nomr 12 Tahun 1951.

4. Tindak Pidana di Zona Ekonomi Eksklusif Indonesia (ZEEI) (Undang-undang Nomor 5 Tahun 1983)

1) Tanpa izin melakukan eksplorasi dan atau eksploitasi sumber daya alam atau kegiatan lainnya untuk eksplorasi dan atau eksploitasi ekonomis seperti pembangkit tenagar air, arus, dan angin (Pasal 16 ayat (1) jo Pasal 5 ayat (1));

2) Tanpa izin membuat dan atau menggunakan pulau-pulau buatan atau instalasi atau bangunan-bangunan lainnya di ZEEI (Pasal 16 ayat (1) jo Pasal 6);

3) Tanpa izin melakukan kegiatan ilmiah di ZEEI (Pasal 16 ayat (1) jo Pasal 7);

4) Dengan sengaja melakukan tindakan yang menyebabkan rusak/tercemarnya linkungan hidup (Pasal 16 ayat (3));

5) Merusak atau memusnahkan barang bukti yang digunakan untuk melakukan tindak pidana di ZEEI (Pasal 17 jo Pasal 16 ayat (1)).

\section{Tindak Pidana Konservasi Sumber Daya Hayati dan Ekosistemnya (Undang-Undang Nomor 5 Tahun 1990)}

1) Dengan sengaja melakukan perbuatan yang dapat mengakibatkan perubahan keutuhan suaka alam (Pasal 40 ayat (1) jo Pasal 19 ayat (1). Jika karena kelalaian (Pasal 40 ayat (3) jo Pasal 19 ayat (1);

2) Dengan sengaja mengambil, menebang, memiliki, merusak, memusnahkan, memelihara, mengangkut dan memperniagakan tumbuhan yang dilindungi atau bagian-bagiannya dalam keadaan hidup atau mati (Pasal 40 ayat (2) jo Pasal 21 ayat (1) huruf a). Jika karena kelalaian (Pasal 40 ayat (3) jo Pasal 21 ayat (1);

3) Dengan sengaja mengeluarkan tumbuhan yang dilindungi atau bagian-bagiannya dalam keadaan hidup atau mati (Pasal 40 ayat (2) jo Pasal 21 ayat (1) huruf b). Jika karena kelalaian (Pasal 40 ayat (4), Pasal 21 ayat (1) huruf b);

4) Dengan sengaja :

a) Menangkap, melukai, membunuh, menyimpan, memiliki, memelihara, mengangkut, dan memperniagakan satwa yang dilindungi dalam keadaan hidup;

b) Menyimpan, memiliki, memelihara, mengangkut, dan memperniagakan satwa yang dilindungi dalam keadaan mati;

c) Mengeluarkan satwa yang dilindungi dari suatu tempat di Indonesia ke tempat lain di dalam atau di luar Indonesia;

d) Memperniagakan, menyimpan atau memiliki kulit, tubuh atau bagianbagian lain satwa yang dilindungi atau barang-barang yang dibuat dari satwa tersebut atau mengeluarkan dari suatu tempat di Indonesia ke tempat lain di dalam atau di luar Indonesia.

e) Mengambil, merusak, memusnahkan, pemperniagakan, menyimpan atau memiliki telur dan atau sarang satwa yang dilindungi; 
5) Dengan sengaja melakukan kegiatan yang mengakibatkan perubahan terhadap keutuhan zona inti taman nasional (Pasal 40 ayat (1) jo Pasal 33 ayat (1). Jika karena kelalaian (Pasal 40 ayat (3) jo Pasal 33 ayat (1));

6) Dengan sengaja melakukan kegiatan yang tidak sesuai dengan fungsi zona pemanfaatan dan zona lain dari taman nasional, taman hutan raya dan taman wisata alam (Pasal 40 ayat (2) jo Pasal 33 ayat (3). Jika kerana kelalaian Pasal 4 ayat (4) jo Pasal 33 ayat (3)).

\section{Tindak Pidana Benda Cagar Budaya} (Undang-undang Nomor 5 Tahun 1992)

1) Pengangkatan benda bersejarah/budaya tanpa izin (Pasal 26);

2) Penggalian, penyelaman, pengangkatan atau cara yang lain untuk mencari benda cagar budaya tanpa izin dari pemerintah (Pasal 27);

3) Mengetahui/menemukan benda berharga asal kapal muatan tenggelam (BMKT) tidak melaporkan kepada pejabat yang berwenang (Pasal $28 \mathrm{c}$ jo Pasal 10 ayat (1)).

\section{Tindak Pidana Keimigrasian (Undang- undang Nomor Tahun 2011).}

1) Setiap orang asing yang tidak melakukan kewajibannya sebagaimana Pasal 71 (Pasal 116);

2) Pemilik atau pengurus tempat penginapan yang tidak memberikan atau tidak memberikan data orang asing yang menginap dirumah (Pasal 117);

3) Setiap yang masuk dan/atau berada di wilayah Indonesia tidak memiliki dokumen perjalanan dan visa yang sah (Pasal 119 ayat (1));

4) Setiap orang asing yang dengan sengaja menggunakan dokumen perjalanan palsu atau dipalsukan (Pasal 119 ayat (2));

5) Setiap orang yang melakukan perbuatan yang bertujuan mencari keuntungan, yang tidak memiliki hak secara sah untuk memasuki wilayah Indonesia, baik dengan dokumen sah ataupun palsu, atau tanpa menggunakan dokumen perjalanan, baik melalui pemeriksaan imigrasi maupun tidak (penyelundupan manusia) Pasal 120 ayat (1));

6) Setiap orang dengan sengaja membuat visa palsu, dan orang asing yang menggunakan visa palsu (Pasal 121);

7) Setiap orang asing yang dengan sengaja menyalahgunakan atau melakukan kegiatan tidak sesuai dengan maksud dan tujuan pemberian izin tinggal (Pasal 122);

8) Setiap orang asing yang dengan sengaja menggunakan visa palsu untuk masuk dan/atau berada di wiayah Indonesia (Pasal 123).

8. Tindak Pidana Psikotropika (Undangundang Nomor 5 Tahun 1997)

1) Melaksanakan pengangkutan ekspor atau impor psikotropika tanpa dilengkapi dengan surat persetujuan ekspor atau impor (Pasal 61 ayat (1) huruf c);

2) Secara tanpa hak memiliki, menyimpan dan/atau membawa psikotropika (Pasal 62);

3) Melakukan pengangkutan psikotropika tanpa dilengkapi dokumen yang sah (Pasal 63 ayat (1) huruf a).

\section{Tindak Pidana Narkotika (Undang-undang Nomor 35 Tahun 2009)}

1) Setiap orang yang tanpa hak atau melawan hukum menanam, memelihara, memiliki, menyimpan, menguasai atau menyediakan Narkotika Golongan I atau Golongan II atau Golongan III (Pasal 111 jo Pasal 112, Pasal 117, Pasal 122);

2) Setiap orang yang tanpa hak atau melawan hukum memproduksi, mengimpor, mengekspor, atau menyalurkan Narkotika Golongan I atau Golongan II atau Golongan III (Pasal113, Pasal 118, Pasal 123);

3) Setiap orang yang tanpa hak melawan hukum menawarkan untuk dijual, menjual, membeli, menerima, menjadi perantara dalam jual beli, menukar atau menyerahkan Narkotika Golongan I atau 
Golongan II atau Golongan III (Pasal 114, Pasal 119 , Pasal 124);

4) Setiap orang yang tanpa hak melawan hukum membawa, mengirim, mengangkut, atau mentransito Narkotika Golongan I atau Golongan II atau Golongan III (Pasal 115, Pasal 120, Pasal 125);

5) Setiap orang yang tanpa hak melawan hukum menggunakan Narkotika Golongan I atau Golongan II atau Golongan III terhadap orang lain atau memberikan Narkotika Golongan I atau Golongan II atau Golongan III (Pasal 116, Pasal 121, pasal 126);

6) Nahkoda yang secara melawan hukum tidak melaksanakan ketentuan Pasal 27. Ketentuan Pasal 27 menentukan sebagai berikut :

a) Narkotika yang diangkut harus disimpan pada kesempatan pertama dalam kemasan khusus atau di tempat yang aman di dalam kapal dengan disegel oleh Nahkoda dengaan saksikan oleh pengirim.

b) Nahkoda membuat berita acara tentang muatan Narkotika yang diangkut.

c) Nahkoda dalam waktu paling lama $1 \mathrm{x}$ 24 (satu kali dua puluh empat) jam setelah tiba di pelabuhan tujuan wajib melaporkan Narkotika yang dimuat dalam kapalnya kepada kepala kantor pabean setempat.

d) Pembongkaran muatan Narkotika dilakukan dalam kesempatan pertama oleh Nahkoda dengan disaksikan oleh pejabat Bea dan Cukai.

e) Nahkoda yang mengetahui adanya Narkotika tanpa dokumen atau Surat Persetujuan Ekspor atau Surat Persetujuan Impor di dalam kapal wajib membuatau Surat Persetujuan Impor di dalam kapal wajib membuat berita acara, melakukan tindakan pengamanan, dan pada persinggahan pelabuhan pertama segera melaporkan dan menyerahkan Narkotika tersebut kepada yang berwenang.
10. Tindak Pidana Lingkungan Hidup (Undang-undang Nomor 23 Tahun 1997)

1) Dengan sengaja melakukan pencemaran dan atau perusakan lingkungan hidup (Pasal 41);

2) Karena kealpaannya melakukan perbuatan yang mengakibatkan pencemaran dan/atau perusakan lingkungan hidup (Pasal 42);

3) Dengan melanggar ketentuan perundangan yang berlaku, sengaja membuang atau melepas zat, energi, dan/atau komponen lain yang berbahaya atau beracun masuk ke dalam air, melakukan impor/ekspor, memperdagangkan, mengangkut, menyimpan bahan tersebut hingga menimbulkan pencemaran lingkungan hidup atau membahayakan keselamatan umum (Pasal 43).

Dalam perkembangannya, Undang-Undang Nomor 23 Tahun 1997 Tentang Lingkungan Hidup, telah direvisi menjadi Undang-Undang Nomor 32 Tahun 2009 Tentang Perlindungan Lingkungan Hidup.

11. Tindak Pidana Kehutanan (Undangundang Nomor 19 Tahun 2004) jo PERPU Nomor 1 Tahun 2004 dan Undang-undang Nomor 19 Tahun 2004

Berdasarkan Undang-undang ini, hanya ada satu jenis tindak pidana, yaitu dengan sengaja mengangkut, menguasai atau memiliki hasil hutan yang tidak dilengkapi bersama-sama Surat Keterangan sahnya hasil hutan (Pasal 78 ayat (7) jo Pasal 50 ayat 3 huruf h).

12. Tindak Pidana Terorisme (Undangundang Nomor 15 Tahun 2003)

1) Secara melawan hukum memasukkan ke Indonesia, membuat, menerima, mencoba memperoleh, menyerahkan atau mencoba menyerahkan, menguasai, membawa, mempunyai persediaan padanya atau mempunyai dalam miliknya, menyimpan, mengangkut, menyembunyikan, mempergunakan atau mengeluarkan ke atau dari Indonesia sesuatu senjata api, amunisi, bahan peledak, dan bahan-bahan lainnya yang berbahaya dengan maksud untuk 


\section{(1) TuJe Akreditasi: Kep. Dirjen.Penguatan Risbang. Kemenristekdikti:}

melakukan tindak pidana terorisme (Pasal 9);

2) Dengan sengaja menggunakan senjata kimia, biologi, radiologi, mikroorganisme, radioaktif atau komponen lainnya sehingga menimbulkan suasana teror atau rasa takut terhadap orang secara meluas menimbulkan korban yang bersifat massal, membahayakan terhadap kesehatan, terjadi kekacauan terhadap kehidupan, keamanan dan hak-hak orang lain atau terjadi kerusakan, kehancuran obyek-obyek vital yang strategi lingkungan hidup, fasilitas publik atau fasilitas internasional (Pasal 10);

Dalam perkembangannya, Undang-Undang Nomor 15 Tahun 2003 direvisi menjadi Undang-Undang Nomor 5 Tahun 2018 Tentang Perubahan Atas Undang-Undang Nomor 15 Tahun 2003 Tentang Pemberantasan Tindak Pidana Terorisme.

13. Tindak Pidana Kepabeanan (Undangundang Nomor 17 Tahun 2006 jo UndangUndang Nomor 10 Tahun 1995).

1) Setiap orang yang :

a) Mengangkut barang impor yang tidak tercantum manifes sebagaimana dimaksud Pasal 7A ayat (2);

b) Membongkar barang impor di luar kawasan Pabean atau tempat lain tanpa izin kepala kantor Pabean;

c) Membongkar barang impor yang tidak tercantum dalam pemberitahuan Pabean sebagaimana dimaksud Pasal 7A ayat (3);

d) Membongkar atau menimbun barang impor yang masih dalam pengawsan Pabean di tempat selain tempat yang ditentukan dan/atau diizinkan;

e) Menyembunyikan barang impor secara melawan hukum;

f) Mengeluarkan barang impor yang belum diselesaikan kewajiban Pabeannya dari kawasan Pabean dari tempat penimbunaan berikat atau dari tempat lain di bawah pengawasan Pabean tanpa persetujuan pejabat Bea dan Cukai yang mengakibatkan tidak terpenuhinya penguatan negara berdasarkan undang-undang ini;

g) Mengangkut barang impor dari tempat penimbunan sementara atau tempat barang penimbunan berikat yang tidak sampai ke kantor Pabean tujuan dan tidak dapat membuktikan bahwa barang tersebut diluar kemampuannya;

h) Dengan sengaja memberikan jenis dan/atau jumlah barang impor dalam pemberitahuan Pabean secara salah, dipidana karena melakukan penyelundupan di bidang impor (Pasal 102).

2) Setiap orang yang :

a) Mengekspor barang tanpa menyerahkan pemberitahuan Pabean;

b) Dengan sengaja memberitahukan jenis dan/atau jumlah barang ekspor dalam pemberitahuan Pabean secara salah sebagaimana dimaksud dalam Pasal 11A ayat (1) yang mengakibatkan tidak terpenuhinya penguatan negara di bidang ekspor;

c) Memuat barang ekspor di dalam daerah Pabean tanpa izin ke kantor Pabean;

d) Membongkar barang ekspor di dalam daerah Pabean tanpa izin kepala kantor Pabean;

e) Mengangkut barang ekspor tanpa dilindungi dokumen yang sah tanpa pemberitahuan Pabean sebagaimana yang dimaksud dalam Pasal 9A ayat (1), dipidana karena melakukan penyelundupan di bidang ekspor (Pasal $102 \mathrm{~A})$.

\section{Tindak Pidana Perikanan (Undang- Undang Nomor 31 Tahun 2004 jo Undang- undang Nomor 49 tahun 2009)}

1) Setiap orang menangkap dan/atau pembudidayaan ikan menggunakan bahan kimia, bahan biologis, bahan peledak, alat dan/atau cara, dan/atau bangunan merugikan dan/atau membahayakan kelestarian Sumber Daya Alam dan/ atau lingkungannya (Pasal 48 ayat (1)); 
2) Nahkoda, ahli penangkapan ikan dan Anak Buah Kapal menangkap dan atau membudidayakan ikan menggunakan bahan kimia, bahan biologis, bahan peledak, alat dan/atau cara, dan/atau bangunan merugikan dan/atau membahayakan kelestarian Sumber Daya Alam dan/atau lingkungannya (Pasal 84 ayat (2));

3) Pemilik kapal, pemilik perusahaan, penanggung perusahaan dan atau operator melakukan usaha penangkapan dan atau pembudidayaan ikan menggunakan bahan kimia, bahan biologis, bahan peledak, alat dan/atau cara, dan/atau bangunan merugikan dan/atau mebahayakan kelestarian Sumber Daya Alam dan/atau lingkungannya (Pasal 84 ayat (3)).

Khusus tindak pidana yang berdimensi ekonomi, juga dilakukan dengan modus operandi penyelundupan melalui jalur laut (perairan Indonesia). Semua kegiatan di bidang kepabeanan yang terkait dengan ekspor dan impor akan berhubungan dengan kegiatan pengangkutan, pembongkaran, penyimpanan, penimbunan yang wajib dilakukan oleh orang yang melakukan kegiatan kepabeanan yang wajib dilakukan dengan melaksanakan dan memasuki ketentuan perundang-undangan kepabeanan atau peraturan lainnya yang berlaku. ${ }^{12}$

Sedangkan fenomena pencemaran di laut, sebagai hal yang membahayakan keamanan maritim, diantaranya tumpahan/kebocoran minyak (oil spill) di laut. Dalam jumlah besar mengakibatkan rusaknya lingkungan dan mempengaruhi pola kehidupan di laut baik yang dilakukan oleh nelayan maupun makhluk hidup lainnya yang menggantungkan hidupnya di laut. ${ }^{13}$ Dalam perkembangan pencemaran di laut, sebagaimana diberitakan oleh berbagai media cetak dan stasiun televisi, warga masyarakat di pesisir utara Karawang, Bekasi dan Jakarta (Kepulauan Seribu) sejak bulan Agustus sampai September 2019 menghadapi pencemaran minyak tumpahan (oil spill) dari kebocoran pipa minyak

\footnotetext{
12 Djafar Albram, Perspektif Kelembagaan Direktorat Jenderal Bea dan Cukai (DJBC) dalam Bidang Pelayanan Kemudahan Impor Tujuan Ekspor (KITE) di Indonesia. Jurnal Penelitian Hukum De Jure, Volume 16, Nomor 1, Maret 2016.
}

milik Pertamina, yang diperkirakan baru akan berhenti pada Oktober 2019.

Berkenaan dengan era globalisasi dan trend kejahatan moderen, keamanan maritim di NKRI juga harus menghadapi dan menyelesaikan kejahatan lintas negara. Salah satu kluster ancaman kejahatan keamanan internasional adalah ancaman yang bersifat lintas batas berupa kejahatan lintas negara (Transnational Organized Crimes). Selain berkembang pesat, kejahatan lintas negara juga memiliki karakteristik yang sangat kompleks

Meningkatnya ancaman kejahatan lintas negara tersebut tidak simetris dengan kemampuan negara untuk mengatasinya, sehingga kerjasama internasional untuk secara kolektif menanggulanginya menjadi solusi sementara dalam penanganannya. Dalam ASEAN Plan of Action to Combat Transnational Crime, terdapat 8 (delapan) jenis kejahatan lintas negara, dimana beberapa jenis diantaranya memiliki dimensi maritim. Termasuk di dalam delapan jenis kejahatan lintas negara tersebut, adalah perdagangan obat-obat terlarang, perdagangan manusia, pembajakan di laut, penyelundupan senjata api dan terorisme (termasuk di dalam kategori ini adalah terorisme maritim), pencucian uang, kejahatan ekonomi internasional, dan kejahatan dunia maya.

Cita-cita to be world-class navy tersusun secara gradual yang dimulau dari the way ahead as a world-class navy, kemudian pursue as a worldclass navy, dan terakhir adalah go forward as a world-class navy. Inilah yang menjadi dasar bagi pembangunan dan pembinaan TNI-AL ke depan untuk dapat mengaplikasikan konsepsi "Sea Power" dalam rangka pertahanan negara dan keamanan dalam arti luas.

Dalam era ketidakpastian ini, TNI-AL tetap berkewajiban untuk senantiasa siap sedia merespon terhadap berbagai tantang dan ancaman bersamasama dengan matra lainnya. Lebih dari itu, TNI-AL juga memiliki kewajiban untuk dapat selalu hadir di setiap arena dalam rangka melindungi kepentingan nasional bangsa Indonesia. Oleh karenanya, The Future of Indonesian Sea Power

\footnotetext{
${ }^{13}$ Muhar Junef, Implementasi Undang-Undang Nomor 32 Tahun 2014 Tentang Kelautan (Studi Kasus Prinsip Pencemar Membayar), Jurnal Penelitian Hukum De Jure, Volume 16, Nomor 4, Desember 2016.
} 
tidak dapat dipisahkan dengan kebutuhan akan eksistensi kekuatan TNI-AL yang andal, profesional, dan disegani pada tataran world-class navy.

Perlu disadari bersama, bahwa untuk mewujudkan hal tersebut diperlukan berbagai upaya yang tidak mudah dan sedikit, kaitannya dengan kebutuhan modernisasi TNI-AL, guna menghadapi tantangan kedepan yang semakin kompleks, serta dalam rangka mengantisipasi berbagai perkembangan lingkungan strategis yang bergerak sangat dinamis. Kebutuhan modernisasi tersebut tidak hanya berhubungan dengan Alat Utama Sistem Senjata (Alutsista), namun juga terkait dengan pembinaan dan pengembangan kompetensi pengawak Alutsista dan organisasi. ${ }^{14}$

Negara kepulauan mempunyai kedaulatan terhadap seluruh daratan/pulau, perairan pedalaman, perairan kepulauan, laut teritorial termasuk ruang udara diatasnya, dasar laut dan tanah dibawahnya, serta sumber daya alam di dalamnya. Wilayah laut/perairan suatu negara kepulauan ditentukan dengan mekanisme penarikan garis pangkal kepulauan (archipelagic baseline). Suatu negara kepulauan dapat menarik garis pangkal lurus kepulauan (archipelagic straight baseline) yang menghubungkan titik dasar di pulau atau karang kering terluar ke titik dasar di pulau atau karang kering terluar lainnya. Perairan yang berada di sisi dalam dari garis pangkal kepulauan itu disebut perairan kepulauan. Churchill dan Lowe menjelaskan karakteristik perairan kepulauan itu sebagai suatu rejim baru dalam hukum internasional dan melakukan elaborasi sebagai such water are neither internal waters nor territorial sea, although they bear a number of resemblances to the latter. Menurut Churchill dan Lowe, perairan kepulauan tidak sama dengan perairan pedalaman dan laut territorial, akan tetapi apabila dilihat dalam konteks hak kewajiban negara lain perairan dan laut dimaksud, maka perairan kepulauan identik dengan laut teritorial.

Adanya perbedaan antara perairan pedalaman, perairan kepulauan, dan laut teritorial pada dasarnya ditentukan oleh hak dan kewajiban negara kepulauan dan juga hak dan kewajiban yang dimiliki oleh negara lain di perairan tersebut. Hak dan kewajiban dimaksud adalah hak pelayaran dan penerbangan yang dimiliki oleh negara asing dan pemanfaatan perairan kepulauan dan laut teritorial oleh negara lain di perairan/laut dimaksud. Sayangnya, Law of the Sea Convention (LOSC) tidak secara jelas mengatur hak dan kewajiban masing-masing pihak di perairan kepulauan. Hal itu tentu saja akan menyulitkan bagi negara kepulauan maupun negara lainnya untuk menentukan hak dan kewajiban yang dapat dilaksanakan di perairan dimaksud. Kondisi ini tentu saja akan menyulitkan negara kepulauan dalam menentukan hak dan kewajibannya termasuk juga melakukan pengaturan terhadap hak dan kewajiban yang dapat dinikmati oleh negara penggguna di perairan kepulauan tersebut.

Kedaulatan yang dimiliki oleh negara kepulauan dapat dilaksanakan dengan memperhatikan pada beberapa hak yang dapat dinikmati oleh negara lain, sebagai contoh memberikan dan mengakomodasikan hak pelayaran melalui perairan kepulauan, kewajiban untuk menghormati perjanjian yang telah ada dengan negara lain sebelum pemberlakuan LOSC, mengakui hak perikanan tradisional, mengakui adanya kegiatan atau aktivitas yang sah lainnya, serta menghormati kabel bawah laut dan memperbolehkan pemeliharaan/penggantian kabel.

\section{B. Model Penegakan Hukum Keamanan Maritim yang Ideal dalam Wilayah NKRI}

Secara legal formal, Indonesia terikat dengan ketentuan-ketentuan dalam UNCLOS 1982, termasuk kewajibannya untuk menjamin keamanan di wilayah laut, khususnya di Sea Lane of Communication ( $S L O C$ ), termasuk pula wilayah yuridiksi nasional yaitu ZEE, Landas Kontinen dan Zona Tambahan. Kewajiban untuk menjaga keamanan dan keselamatan pelayaran internasional ini tidak dapat diabaikan. Apabila kapal-kapal negara lain merasa terancam keamanannya saat melintas maupun melakukan kegiatan yang sah di sekitar perairan Indonesia, maka hal ini dapat menjadi alasan untuk menghadirkan kekuatan laut negaranya.

\footnotetext{
14 Marsetio. Sea Power Indonesia (Universitas Pertahanan, 2014), hlm. 124-125.
} 
Berkaitan dengan hal-hal tersebut diatas, maka diperlukan persamaan persepsi tentang dimensi keamanan laut, khususnya bagi seluruh komponen bangsa yang memiliki tugas, fungsi dan kewenangan dilaut, agar "action plan" dapat dilaksanakan tepat sasaran, terarah dan terpadu. Perlu dipahami pula, bahwa keamanan laut bukan hanya menyangkut aspek penegakan hukum semata-mata, karena keamanan laut tidak sama dengan penegakan hukum di laut. Keamanan di laut memiliki dimensi yang jauh lebih luas daripada aspek penegakan hukum. Dimensi keamanan laut mengandung pengertian bahwa laut aman digunakan dan bebas dari ancaman dan gangguan terhadap aktivitas penggunaan atau pemanfaatan laut yang mencakup hal-hal sebagai berikut :

1) Lautan terbebas dari ancaman kekerasan (free from violence threat);

Termasuk ke dalam ancaman jenis ini yaitu ancaman dengan menggunakan kekuatan senjata yang terorganisir dan memiliki kemampuan untuk mengganggu dan membahayakan personel atau negara. Ancaman tersebut dapat berupa pembajakan, perompakan, sabotase objek vital, peranjauan, dan aksi teror bersenjata;

2) Lautan terbebas dari ancaman navigasi (free from navigation threat);

Termasuk ke dalam ancaman jenis ini yaitu ancaman yang ditimbulkan oleh kondisi geografi dan hidrografi serta kurang memadainya sarana bantu navigasi serta informasi pelayaran yang dapat membahayakan keselamatan pelayaran.

3) Lautan terbebas dari ancaman terhadap lingkungan dan sumber daya laut (free from natural resources tribulation).

Termasuk ke dalam ancaman jenis ini yaitu pencemaran dan perusakan ekosistem laut, eksploitasi yang berlebihan serta konflik pengelolaan sumber daya laut. Fakta menunjukkan bahwa konflik pengelolaan sumber daya laut memiliki kecenderungan mudah dipolitisir, dan selanjutnya dengan penggelaran kekuatan militer asing.

\footnotetext{
15 Naskah Akademik Rancangan Undang-undang
} Tentang Perubahan Undang-undang Nomor 1 Tahun
4) Lautan terbebas dari ancaman pelanggaran hukum (free from law transgression threat) ${ }^{15}$

Termasuk ke dalam ancaman jenis ini yaitu tidak dipatuhinya hukum nasional maupun hukum internasional yang berlaku di laut, seperti : illegal fishing, illegal logging, illegal immigrant, penyelundupan, dan lain-lain.

Ketentuan-ketentuan Konvensi Hukum Laut 1982 yang berlaku bagi semua kapal-kapal asing, pada Pasal 19 ayat (2) menyebutkan tentang daftar dari kegiatan-kegiatan dari kapal asing yang dianggap tidak damai :

(a) Melakukan ancaman atau menggunakan kekerasan kedaulatan, keutuhan wilayah, kemerdekaan politik negara pantai, atau dengan cara lain apapun yang melanggar prinsip-prinsip hukum;

(b) Melakukan pelatihan perang atau praktik dengan senjata macam apapun;

(c) Melakukan perbuatan yang bertujuan untuk mengumpulkan informasi yang merugikan bagi pertahanan atau keamanan negara pantai;

(d) Melakukan perbuatan yang melakukan propaganda yang bertujuan mempengaruhi pertahanan atau keamanan negara pantai;

(e) Meluncurkan, mendaratkan, atau menaikkan suatu pesawat udara dari atau ke atas kapal;

(f) Meluncurkan, mendaratkan, atau menaikkan suatu peralatan dan perlengkapan militer dari atau ke atas kapal;

(g) Membongkar atau memuat setiap komoditi, mata uang atau orang dengan cara yang bertentangan dengan peraturan perundangan di biedang Bea Cukai, fiskal, imigrasi dan saniter;

(h) Melakukan perbuatan pencemaran yang dilakukan dengan sengaja dan menimbulkan pencemaran yang parah;

(i) Melakukan kegiatan penangkapan ikan secara ilegal;

(j) Melakukan kegiatan riset atau survei tanpa izin dari negara pantai; 
(k) Melakukan perbuatan yang bertujuan untuk mengganggu sistem informasi, setiap fasilitas atau instalasi komunikasi lainnya; dan

(1) Melakukan kegiatan lain yang tidak berhubungan langsung dengan lintas. ${ }^{16}$

Di tengah konsentrasi pemerintah dan negara untuk penegakan keamanan maritim, yang harus dicermati secara mendalam dan antisipatif, antara lain potensi konflik akibat sengketa wilayah maritim. Di Laut Tiongkok Selatan. Sengketa Laut Tiongkok Selatan sebenarnya sudah terjadi lebih dari 20 tahun lamanya, yaitu sejak tahun 1974 hingga 2011. Namun, ketegangan yang baru-baru ini terjadi menimbulkan kekhawatiran baru di kawasan ini dan semakin mengancam ketahanan dan keamanan dunia. Titik sengketa Laut China Selatan adalah Kepulauan Spratly. Sengketa atas kepemilikan Kepulauan Spratly dan Kepulauan Paracel mempunyai riwayat yang panjang dan berbatasan dengan wilayah perairan dari beberapa negara, seperti Filipina, Vietnam, Indonesia, dan Malaysia. Kepulauan ini terletak kurang lebih 110 kilometer dari pelabuhan Yu Hin (Pulau Hainan, Tiongkok) dan 500 kilometer dari pantai Kalimantan Bagian Utara. Pada tahun 2011 Tiongkok bertemu dengan negara anggota ASEAN dan sepakat untuk nenbicarakan tata cara penyelesaian Laut Tiongkok Selatan yang hingga kini belum menemukan penyelesaian. Tiongkok tidak pernah menjelaskan posisi kedaulatannya di Laut Tiongkok Selatan secara hukum internasional, padahal mereka sudah meratifikasi perjanjian konvensi tentang Hukum Laut. ${ }^{17}$

Indonesia hingga saat ini juga masih mempunyai pekerjaan rumah untuk menyelesaikan perbatasan laut teritorial dengan Malaysia, Singapura, dan Timor Leste. Perbatasan ZEE dengan Malaysia, India, dan Palau serta perbatasn Landas Kontinen dengan Malaysia dan Palau.

Perlu dicacat, sesuai Pasal 56 UNCLOS 1982, kewenangan negara dan ZEE bukanlah sebuah kedaulatan (sovereignty), melainkan hak berdaulat (sovereign rights). Hal itu berarti negara memiliki kewenangan penegakan hukum yang

\footnotetext{
${ }^{16}$ Dikdik Mohammad Sodik. Hukum Laut Internasional dan Pengaturannya di Indonesia. Bandung, Refika Aditama, 2014 hlm. 28-29.

17 Muhar Junef. Sengketa Wilayah Maritim di Laut Tiongkok Selatan. Jurnal Penelitian Hukum De Jure Volume 18 Nomor 2, Juni 2018 hlm. 223.
}

terbatas pada sumber daya kelautan, baik hayati maupun non-hayati di kolom air zona ini. Hal mana akan berbeda dengan status laut wilayah yang berlaku seluruh hukum nasional dari negara pantai secara penuh.

Regulasi yang berlaku di atas permukaan ZEE adalah rezim laut bebas dimana terdapat beberapa kebebasan bagi kapal asing. Oleh karena itu, wilayah permukaan air diatas ZEE seringkali disebut laut bebas yang khusus (sui generis) karena masih terdapat hak berdaulat negara pantai di kolom airnya.

Sesuai dengan hukum internasional, negara yang memiliki wilayah laut berbatasan diwajibkan melakukan negosiasi dalam mencapai kesepakatan atas batas wilayahnya. UNCLOS 1982, telah memberikan petunjuk bagaimana negara pantai bisa menyepakati batas wilayah lautnya, termasuk ZEE.

Dalam menyelesaikan perundingan batas wilayahnya, tidak ada batas waktu yang diberikan kepada negara-negara dalam hukum internasional. Akan tetapi, semakin lama proses kesepakatan itu tertunda, insiden-insiden seperti yang telah terjadi antara Indonesia dan Vietnam akan kerap terjadi. Saling klaim dan sama-sama merasa berwenang dalam penegakan hukum di wilayah tersebut.

Pasal 15, Pasal 74, dan Pasal 83 UNCLOS 1982 pada dasarnya telah mengatur bagaimana delimitasi batas maritim antarnegara seharusnya dilakukan. Khususnya Pasal 74, UNCLOS memberikan mandat kepada negara-negara yang sedang berunding untuk membuat sebuah kesepakatan atau pengaturan sementara yang bertujuan untuk tidak melakukan tindakantindakan yang saling merugikan dan menghambat proses pencapaian kesepakatan batas wilayah itu. ${ }^{18}$

Problematika penegakan keamanan maritim dalam kawasan NKRI, selain sengketa Laut Tiongkok Selatan, dengan klaim sepihak dari Negara Tiongkok, juga berkenaan dengan pembangunan-pembangunan fisik di laut yang berbatasan dengan negara lain. Termasuk disini perjanjian pemasangan kabel listrik,

18 Arie Afriansyah, Batas Wilayah Laut dan Hak Berdaulat, dimuat dalam Kompas Edisi Rabu 8 Mei 2019. 
telekomunikasi, dan pipa minyak bawah laut, dan juga tentang reklamasi di laut yang berbatasan dengan negara lain.

Sebagai perkembangan terkini dari reklamasi di laut yang berpotensi mengancam keamanan maritim, bahkan mengancam kedaulatan suatu negara, yaitu reklamasi di pantai Singapura. Kejadian reklamasi di laut bisa saja terjadi di berbagai negara lain yang luas daratannya terbatas, namun perkembangan ekonomi dan perdagangan meningkat pesat. Hal ini juga mengancam keamanan maritim dan menjadi sengketa perbatasan laut dengan negara tetangga.

Perdana Menteri Malaysia Mahathir Muhammad memberlakukan pelarangan seluruh aktivitas ekspor pasir laut dari neganya ke Singapura. Pelarangan itu berlaku sejak 3 Oktober 2018 atau sekitar lima bulan setelah dirinya dilantik kembali menjadi Perdana Menteri. Mahathir disebutkan marah karena tanah asal Malaysia dimanfaatkan untuk memperluas wilayah negara tetangga yang lebih kaya.

Rencana itu antara lain mencakup pengembangan Pelabuhan Tuas yang digadanggadang menjadi terminal peti kemas terbesar di dunia. Singapura telah meningkatkan luas daratannya seperempat kali lebih luas dibandingkan dengan luas daratannya saat negara itu memproklamasikan kemerdekaannya, dengan memisahkan diri dari Malaysia pada tahun 1965. Sebagian besar langkah Singapura memperluas wilayah daratan dilakukan melalui reklamasi wilayah pesisir dengan pasir.

Setelah berpisah pada tahun 1965, Singapura dan Malaysia mengalami dinamika dalam hubungan, termasuk perselisihan mengenai wilayah dan sumber daya bersama seperti air. ${ }^{19}$

Kementerian Lingkungan Hidup yang sekarang berubah namanya menjadi Kementerian Lingkungan Hidup dan Kehutanan mencatat, kerugian yang dialami Indonesia mencapai Sin $\$ 42,38$ miliar. Setiap hari, ada 29 kali kapal hilir mudik pembawa ribuan meter kubik pasir laut dari Riau menuju Singapura. Kapal tersebut

\footnotetext{
${ }^{19}$ Kompas, Malaysia Stop Ekspor Pasir, Kamis 4 Juli 2019.

${ }^{20}$ Puput Tripeni Juniman, CNN Indonesia, Berkaca dari Reklamasi di Singapura, Jumat, 15/04/2016,
}

berkapasitas muat berkisar antara 1.000-4.000 meter kubik sekali angkut. Akibat mengambil pasir dari daratan Indonesia, luas wilayah Singapura maju sejauh $12 \mathrm{~km}$ ke arah perbatasan Indonesia mendekati pulau terluar, Pulau Nipah, Kepulauan Riau. Perairan di pulau tersebut mengalami kenaikan yang menyisakan daratan beberapa meter dari permukaan laut. Wilayah perairan internasional termasuk lebar jalur pelayaran antara Singapura dan Batam akan tergeser. Perubahan itu otomatis juga akan menggeser masuk wilayah perairan Indonesia, karena lebar jalur pelayaran dihitung dari titik terluar garis pantai, ${ }^{20}$

Konsistensi NKRI melaksanakan kedaulatan wilayahnya, termasuk dalam kawasan maritim, suatu penegakan hukum untuk mewujudkan keamanan maritim, telah dan terus menerus dilakukan. Kerjasama institusi terkait seperti Ditjen Bea Cukai, Bakamla, Ditjen Imigrasi, Polair, Kementerian Lingkungan Hidup, Kementerian Kelautan dan Perikanan, serta TNI-AL. Posisi dan eksistensi TNI-AL dalam penegakan keamanan maritim NKRI, adalah melekat sebagai unsur utama pertahanan di laut wilayah NKRI, dan pelaksanaan tugas keamanan maritim bagi TNI AL adalah perwujudan Operasi Militer Selain Perang (OMSP) sesuai Undang-Undang Nomor 34 Tahun 2004 Tentang TNI, pada Pasal 7 Ayat (2) Poin b. OMSP adalah sangat strategis dan dominan. Problem utama dalam mengoperasionalkan TNIAL secara maksimal, tidak lain adalah jumlah kapal perang dan kapal pendukungnya yang masih terbatas. Sehingga optimalisasi TNI-AL untuk menjaga keamanan maritim NKRI tetap terkendala.

Kepala Staf Angkatan Laut (KASAL) Laksamana TNI Siwi Sukma Aji memaparkan beberapa persoalan besar yang sifatnya struktural yang dihadapi oleh TNI-AL, diantaranya persoalan anggaran yang sangat terbatas. Padahal seharusnya TNI-AL memerlukan Alat Utama Sistem Persenjataan (Alutsista) yang mengikuti perkembangan zaman untuk memperkuat aspek pertahanan. Kami mengajukan anggaran untuk tahun 2019 sebesar Rp.439 triliun, hanya dipenuhi Rp. 14,3 triliun atau hanya $33,36 \% .{ }^{21}$

https://www.cnnindonesia.com/nasional/20160415172 432-20-124254/berkaca-dari-reklamasi-di-singapura.

${ }^{21}$ Rountable Discussion bertema "Wilayah Negara dan Pertahanan dan Keamanan Negara Menurut UUDRI 


\section{De Jure}

NKRI, sebagai bangsa yang mengedepankan perdamaian dunia, serta berupaya bekerjasama secara serius dan mendalam dengan negara lain, dan organisasi internasional lainnya, pendekatan dan penyelesaian keamanan maritim khususnya di NKRI, selalu dikomunikasikan secara intensif dengan negara-negara lain dan organisasi internasional, untuk mencari kesepakatan.

Sebagai eksistensi negara yang berdaulat, menurut Black Law Dictionary, negara diartikan sebagai "The political system of a body of people who are politically organized", dan negara adalah suatu organisasi kekuasaan. Negara adalah organisasi yang dapat memaksakan kehendaknya. ${ }^{22}$ Negara yang berdaulat adalah negara merdeka yang satu bebas dari yang lainnya, juga mempunyai derajat yang sama dengan lainnya. ${ }^{23}$

\section{KESIMPULAN}

Perwujudan keamanan maritim dalam wilayah NKRI, khususnya pada aspek penegakan hukum sangat terkendala. Kompleksitas wilayah laut NKRI dengan ribuan pulau besar dan kecil, baik yang berpenghuni maupun kosong, dengan kekayaan laut yang melimpah mengundang berbagai pihak asing untuk memanfaatkannya. Sebagai negara kepulauan, NKRI dapat diibaratkan rumah tanpa pagar, siapapun dapat keluar masuk tanpa dapat dideteksi secara dini.

Kompleksitas keamanan maritim NKRI, diawali dengan masih adanya wilayah perbatasan laut antara NKRI dengan berbagai negara tetangga, yang belum mencapai kesepakatan batas wilayah. Dalam kasus-kasus pencurian ikan, dan klaim atas wilayah antara NKRI dengan negara tetangga, telah berkali-kali terjadi. Sedangkan tindak pidana di laut, yang sangat beragam, diantara para pelaku tindak pidana di laut, adalah Warga Negara Asing (tetangga), bahkan terkadang dikawal oleh Angkatan Laut/Penjaga Pantai negara asing tersebut.

Perkembangan baru tentang keamanan maritim yang sesungguhnya telah terjadi sejak 15

Tahun 1945”, Lembaga Pengkajian MPR, Selasa 2 Juli 2019. Koran Sindo Rabu 3 Juli 2019.

22 Sudjijono \& Bagus Teguh Santoso. Hukum Kepolisian Studi Kekuasaan dan Rekonstruksi Polri tahun yang lalu adalah reklamasi pantai di Singapura. Pada waktu itu, secara tersamar Singapura mengimpor pasir dari Indonesia, dan pada kenyataannya pasir tersebut bukan saja untuk pembangunan gedung/perkantoran dan sarana lainnya. Namun untuk reklamasi pantai di Singapura. Secara sadar Malaysia mulai menghentikan ekspor pasir ke Singapura, karena terbukti pasir tersebut untuk memperluas wilayah pantai.

Sebagai konsekuensi logis perluasan wilayah pantai berangkat dari setiap ekspor pasir Malaysia ke Singapura, dapat dipastikan bahwa akan terjadi pergeseran batas wilayah laut antara Malaysia dengan Singapura. Begitu juga antara wilayah laut Indonesia dengan Singapura. Yang sangat diuntungkan adalah Singapura, sedangkan yang merugi adalah Malaysia dan Indonesia.

Sengketa wilayah di Laut Tiongkok Selatan antara negara Tiongkok dengan beberapa negara tetangga, dapat berimbas pada ZEE Indonesia, dan ancaman terhadap pertahanan negara. Keamanan maritim dapat dipastikan terganggu, penggunaan alat utama persenjataan (Alutsista) modern jika sampai terjadi konflik bersenjata, sangat membahayakan kawasan maritim termasuk di laut yang berbatasan langsung dengan NKRI.

Dalam menangani keamanan maritim, berbagai instansi terkait telah lama bertanggung jawab, termasuk Bakamla, yang baru sekitar 4 (empat) tahun mengawal keamanan laut. Sinergitas instansi terkait Ditjen Bea Cukai, Ditjen Imigrasi, KKP, Polri, KLH, TNI AL dan berbagai pihak lainnya, sudah cukup memadai. Hanya saja, kendala utama keterbatasan sumber daya manusia, sarana dan prasarana, dana operasional.

Keamanan maritim dalam wilayah NKRI, merupakan tanggung jawab mutlak pada NKRI. Berbagai kendala dalam mewujudkan keamanan maritim, pada perjanjian perbatasan laut dengan negara tetangga, masih ada yang belum terealisir. Kesepakatan untuk bersepakat tentang perjanjian perbatasan wilayah laut, ternyata masih sulit dilaksanakan. Pada tingkat Kepala Negara/Kepala

dalam Fungsi Pemerintahan. Penerbit Laksbang Surabaya 2017 hlm 170.

23 Mochtar Kusumaatmadja. Pengantar Hukum Internasional. Penerbit PT Alumni Bandung 2003 hlm. 16. 
Pemerintahan seringkali terbentur di tingkat pelaksanaannya.

Dalam aspek kerja sama penegakan hukum di laut, yang dilakukan antar negara, isu-isu yang mudah diselesaikan adalah menyangkut tindak pidana pembajakan/perompakan d laut. Sedangkan permasalahan pencurian ikan, dan pencemaran laut, selalu membutuhkan jalur diplomasi yang panjang.

Penguatan dan pembaruan peraturan perundang-undangan untuk mendukung pengamanan maritim NKRI dalam arti luar, terus dilakukan. Diantaranya untuk merevisi UndangUndang Nomor 1 Tahun 1973 Tentang Landas Kontinen Indonesia. Sedangkan penegakan keamanan maritim yang ideal dalam wilayah NKRI, memerlukan keseriusan, dan konsistensi dari instansi terkait.

\section{SARAN}

Berkenaan bahwa keamanan maritim dalam NKRI, berawal dari belum seluruhnya wilayah perbatasan laut dengan negara tetangga, terdapat perjanjian antar negara, Kementerian Luar Negeri dan instansi terkait perlu segera merealisasikan perjanjian perbatasan laut dengan negara tetangga yang belum terwujud. Di samping berbagai peraturan perundang-undangan terkait yang belum selaras atau sudah ketinggalan zaman, perlu diusulkan untuk direvisi.

Penguatan SDM, sarana dan prasarana pada berbagai instansi yang juga menangani keamanan maritim, yaitu Ditjen Bea dan Cukai, Ditjen Imigrasi, KLH, Polri, Bakamla, TNI AL, dan instansi yang lain, harus segera diwujudkan. Khusus TNI AL sebagai unsur pertahanan negara di laut, dan juga unsur utama keamanan maritim, yang masih menuju Minimum Essential Force (MEF) dalam penyediaan Alutsista, harus dipenuhi penganggaran secara lebih progresif.

Kerja sama internasional dalam menangani keamanan maritim NKRI, tetap harus dijaga, dan ditingkatkan. Karena bagaimanapun, kehidupan berbangsa, dan bernegara untuk kesejahteraan rakyat di semua negara, bergantung pada laut atau maritim.

\section{UCAPAN TERIMA KASIH}

Penegakan keamanan maritim dalam NKRI merupakan permasalahan yang sangat mendasar dan sekaligus mendesak sebagai perwujudan negara hukum yang berdaulat. menyadari bahwa keamanan maritim belum sepenuhnya dikelola dan diimplementasikan dengan baik, maka penulis dengan segala upaya mencoba untuk melakukan penelitian hukum yang berjudul Penegakan Keamanan Maritim dalam NKRI dan Problematikanya.

Tentu saja dalam upaya melakukan penelitian hukum ini terdapat kekurangan dan keterbatasan, untuk itu secara pribadi saya mengucapkan terima kasih kepada Dewan Redaksi Jurnal Ilmiah De Jure dan Reviewer yang telah mengoreksi hasil penelitian hukum ini, sehingga dapat diterbitkan dalam Jurnal Ilmiah De Jure. Semoga Allah SWT memberikan petunjuk kepada kita semua.

\section{DAFTAR KEPUSTAKAAN}

Angga Nurdin Rachmat. Keamanan Global Transformasi Isu Keamanan Pasca Perang Dingin. Penerbit Alfabeta. Bandung 2015.

Bernhard Lembong. Poros Maritim. Penerbit Margaret Pustaka. Jakarta. 2015.

Dikdik Mohammad Sodik. Hukum Laut Internasional dan Pengaturannya di Indonesia. Penerbit Refika Aditama Bandung 2015.

Djafar Albram. Perspektif Kelembagaan Direktorat Jenderal Bea dan Cukai (DJBC) dalam Bidang Pelayanan Kemudahan Impor Tujuan Ekspor (KITE) di Indonesia. Jurnal Penelitian Hukum De Jure, Volume 16, Nomor 1, Maret 2016.

Hadari Nawawi. Metode Penelitian Sosial, Penerbit Gajahmada Pers Yogyakarta 1993.

Jokowi \& Jusuf Kalla, Jalan Perubahan untuk Indonesia yang Berdaulat, Mandiri dan Berkepribadian: Visi, Misi, dan Program Aksi, Jakarta, Mei 2014, diunduh dari https://www.bantuanhukum.or.id/web/wpcontent/uploads/2014/06/VISI MISI Joko wi-JK.pdf. 
Kresno Buntoro. Alur Laut Kepulauan Indonesia (ALKI) Prospek dan Kendala. Penerbit SEKOAL TNI-AL Jakarta 2012.

Laporan Penelitian Hukum Tentang Penegakan Hukum di Perairan Indonesia. BPHN Kemenkumham 2015.

Marsetio. Sea Power Indonesia. Cetakan Pertama April 2014. Penerbit Universitas Pertahanan Jakarta 2014.

Mochtar Kusumaatmadja. Pengantar Hukum Internasional. Penerbit Alumni Bandung 2003.

Muhar Junef. Sengketa Wilayah Maritim di Laut Tiongkok Selatan. Jurnal Penelitian Hukum De Jure Volume 18 Nomor 2, Juni 2018.

Implementasi Undang-Undang Nomor 32 Tahun 2014 Tentang Kelautan (Studi Kasus Prinsip Pencemar Membayar). Jurnal Penelitian Hukum De Jure, Volume 16, Nomor 4, Desember 2016.

Naskah Akademik Rancangan Undang-Undang Tentang Perubahan Undang-undang Nomor 1 Tahun 1973 Tentang Landas Kontinen Indonesia, BPHN Kemenkumham 2013.

Sadjijono \& Bagus Tegus Santoso. Hukum Kepolisian Indonesia Studi Kekuasaan dan Rekonstruksi Polri dalam Fungsi Pemerintahan. Penerbit Laksbang Surabaya 2017.

Soerjono Soekanto \& Sri Mamudji. Penelitian Hukum Normative Suatu Tinjauan Singkat. Penerbit Rajawali Pers, Jakarta 1990.

Suharyo. Dinamika Peranan TNI dalam Penegakan Hukum dan Kedaulatan NKRI, Penerapan Keadaan Bahaya \& OMSP di Negara Demokrasi. Penerbit Pohon Cahaya. Yogyakarta. 2016.

Ani Afriansyah. Batas Wilayah Laut dan Hak Berdaulat. Dimuat dalam Kompas, Rabu 8 Mei 2019.

Kompas Diplomasi Maritim Kebijakan Kelautan Berorientasi Keluar. Sabtu 23 Februari 2019.

Kompas Malaysia Stop Ekspor Pasir. Kamis 4 Juli 2019.

Sindo Roundtable Discussion Lembaga Pengkajian MPR, Rabu 3 Juli 2019. 